\title{
KOMPETENSI ARSITEK DALAM MENDUKUNG TERWUJUDNYA KOTA HIJAU
}

\author{
Margareta Maria Sudarwani \\ Universitas Pandanaran \\ Jl. Banjarsari Barat No. 1, Pedalangan, Banyumanik, Semarang \\ email: maria.sudarwani@yahoo.co.id
}

\begin{abstract}
Abstrak
Pembangunan wilayah perkotaan perlu memasukkan unsur lingkungan sebagai salah satu dasar pertimbangan dalam pembangunan sumber daya alam dan lingkungan hidup sebagai suatu strategi Pembangunan Berkelanjutan (Sustainable Development), bertujuan untuk memaksimalkan keuntungan pembangunan dengan tetap menjaga kualitas sumber daya alam dan untuk mendayagunakan seluruh potensi sumber daya alam yang ada guna mencukupi kebutuhan pembangunan dan aktivitas kehidupan ekonomi masyarakat sebatas kemampuan dan daya tampungnya dalam kerangka pembangunan yang berwawasan lingkungan. Ruang Terbuka Hijau (RTH) sebagai bagian dari penataan ruang kota perlu ditetapkan keberadaannya secara serius, direncanakan secara menyeluruh dan diperkuat dengan peraturan yang tegas untuk memperjelas status hukumnya. Dengan demikian pengembangan dan pengelolannya lebih terarah serta dapat menghindari perubahan fungsi Ruang Terbuka Hijau menjadi fungsi lainnya, dan mengupayakan terciptanya Kota Hijau sebagai bagian dari Ruang Terbuka Publik di kawasan perkotaan.

Kajian ini bertujuan untuk meneliti seberapa besar capaian sasaran dan manfaat yang diperoleh dalam menambah besaran luasan Ruang Terbuka Hijau (RTH) di Kota Semarang, serta bagaimana peran seorang Arsitek dalam mengimplementasikan komponen guna mendukung terciptanya Kota Hijau.

Penelitian ini menggunakan Metode Rasionalistik berlandaskan pada cara berpikir rasionalisme, yang berasal dari pemahaman kemampuan intelektual dan dibangun atas kemampuan argumentasi secara logika, sehingga lebih ditekankan pada pemaknaan empiri (Sutrisno Hadi, 1984).

Secara Kuantitas dan Kualitas, Sebaran dan Besaran Ruang Terbuka Hijau di wilayah Kota Semarang masih perlu ditingkatkan lagi karena masih sangat sulit untuk menyediakan luasan lahan yang cukup yang dapat dimanfaatkan sebagai Ruang Terbuka Hijau baru. Upaya untuk memanfaatkan lahan kosong, lahan kritis, sempadan sungai dan lahan bekas bongkaran bangunan publik merupakan salah satu upaya untuk menambah luasan RTH di Kawasan Perkotaan.
\end{abstract}

Kata Kunci : Ruang Terbuka Hijau, Ruang Terbuka Publik, Kota Hijau

\section{PENDAHULUAN}

Pertumbuhan wilayah perkotaan berimplikasi pada berkurangnya ruang terbuka (non terbangun). Hal ini disebabkan perkembangan wilayah kota yang diakibatkan oleh pertumbuhan penduduk serta meningkatnya lahan terbangun untuk pemenuhan lahan fasilitas dan fungsi-fungsi perkotaan yaitu meningkatnya suhu lingkungan, meningkatkan tingkat kebisingan, meningkatnya run off (limpasan air) hujan, serta mengkatnya dampak polusi lainnya.

Petumbuhan dan perkembangan Kota Semarang terlihat dari meningkatnya lahan terbangun. Lahan terbangun (pekarangan \& bangunan) Kota Semarang pada tahun 2005 terjadi penambahan sebesar 24.96 ha untuk permukiman dan 5.38 ha untuk kegiatan industri, pada tahun 2010 terjadi penambahan sebesar 67.09 ha untuk permukiman dan penambahan sebesar 10.42 ha untuk lahan industri (Bappeda Kota Semarang, 2010).

Penambahan lahan terbangun tersebut berdampak pada penurunan kualitas lingkungan hidup perkotaan, baik pada lingkungan udara, lingkungan air, lingkungan tanah maupun lingkungan visual perkotaan. Untuk itu perlu dirumuskan kebijakan pengelolaan dan pengembangan Tata Ruang Hijau perkotaan untuk dapat meningkatkan 
kualitas lingkungan hidup perkotaan (Sumarwoto, 1989).

Dampak perubahan penggunaan fungsi lahan dan eksploitasi terhadap sumber daya alam, kemajuan sosial ekonomi dan tekanan penduduk yang menuntut penanganan kawasan kota secara menyeluruh dan terpadu agar dapat terjadi keselarasan antara lingkungan dengan dinamika penduduk serta terjadinya ketidakseimabngan antara tekanan penduduk dan sumber daya alam yang menimbulkan masalah lingkungan yang terjadi di Kota Semarang menjadi salah satu kendala dalam mengimplementasikan Program Pembangunan Berkelanjutan yang telah dicanangkan Pemerintah Kota setempat. Beberapa permasalahan yang terjadi sebagai akibat makin berkurangnya Ruang Hijau sebagai penyeimbang ekosistem kota, diantaranya adalah sebagai berikut (Bappeda Kota Semarang, 2006) :

1. Terjadi perubahan iklim mikro berupa kenaikan suhu, yang membuat kota menjadi tidak nyaman untuk ditinggali, dibandingkan kondisi beberapa tahun sebelumnya.

2. Keringnya sumber-sumber air pada saat musim kemarau

3. Meningkatnya zat-zat polutan dalam udara, sebagai indikasi kerusakan lingkungan yang serius, yang jika tidak segera diatasi akan mengganggu kesehatan, kenyamanan, mengurangi produktivitas kerja serta meningkatnya biaya operasionjal pembangunan.

Ruang Hijau (RH) sebagai bagian dari penataan ruang kota perlu direncanakan secara menyeluruh dan diperkuat dengan perda-perda yang tegas untuk memperjelas status hukumnya, dengan demikian pengembangan dan pengelolannya lebih terarah serta dapat menghindari perubahan fungsi Ruang Hijau menjadi fungsi lainnya. Hal ini sesuai dengan Instruksi Menteri Dalam Negeri (Inmendagri) Nomor 14 Tahun 1988, tentang Penataan Ruang Hijau (RH) di Wilayah Perkotaan, yang kemudian ditindaklanjuti dengan menginstruksikan kepada Kepala Daerah dari tingkat Propinsi hingga Kabupaten/Kota untuk merencanakan, melaksanakan dan mengendalikan penyelenggaraan penataan Ruang Hijau serta melaksanakan pengelolaan dan pengendalian untuk meningkatkan peran dan fungsi Ruang Hijau. Untuk itu, agar kebijakan tersebut dapat berjalaneq dengan sebagaimana mestinya, maka diperlukan penyerahan kewenangan yang jelas kepada dinas/lembaga pemerintah sebagai leading sector pengembangan dan pengelolaan Ruang Hijau.

Undang-Undang No.26 Tahun 2007 tentang penataan ruang, di dalam Pasal 29 antara lain telah mengamanatkan secara tegas bahwa 30\% dari wilayah kota/kawasan perkotaan harus berwujud Ruang Terbuka Hijau (RTH), dengan komposisi 20\% RTH Publik dan 10\% RTH Privat. Preskripsi RTH $30 \%$ tersebut merupakan kewajiban yang harus dipenuhi oleh Pemerintah Kota/Kabupaten dan termuat didalam Peraturan Daerah (Perda) tentang RTRW Kota/Kabupaten. Hal ini dilakukan dalam rangka mewujudkan kota/kawasan perkotaan yang berkelanjutan.

Peraturan Menteri Dalam Negeri (Permendagri) Nomor 1 Tahun 2007 Tentang Penataan Ruang Terbuka Hijau Kawasan Perkotaan, menyebutkan bahwa perkembangan dan pertumbuhan kota/perkotaan disertai dengan alih fungsi lahan yang pesat, telah menimbulkan kerusakan lingkungan yang dapat menurunkan daya dukung lahan dalam menopang kehidupan masyarakat di kawasan perkotaan, sehingga perlu dilakukan upaya untuk menjaga dan meningkatkan kualitas lingkungan melalui penyediaan ruang terbuka hijau yang memadai. Di dalam Pasal 9 peraturan tersebut ditegaskan kembali bahwa Luas Ideal Ruang Terbuka Hijau Kawasan Perkotaan (RTHKP) minimal 20\% dari luas kawasan perkotaan.

Peraturan Menteri Pekerjaan Umum Nomor 5 Tahun 2008 Tentang Pedoman Penyediaan Dan Pemanfaatan Ruang Terbuka Hijau Di Kawasan Perkotaan menegaskan bahwa kuantitas dan kualitas ruang terbuka publik terutama Ruang Terbuka Hijau (RTH) saat ini mengalami penurunan yang sangat signifikan dan mengakibatkan penurunan kualitas lingkungan hidup perkotaan yang berdampak keberbagai sendi kehidupan perkotaan antara lain sering terjadinya banjir, peningkatan pencemaran udara, dan menurunnya produktivitas masyarakat akibat terbatasnya ruang yang tersedia untuk interaksi sosial. Di dalam peraturan tersebut diatur mengenai penyediaan dan pemanfaatan 
Ruang Terbuka Hijau di Kawasan Perkotaan serta prosedur perencanan dan peran serta masyarakatnya.

Sedikitnya jumlah ruang-ruang terbuka di daerah perkotaan menjadi salah satu faktor tingginya tekanan kehidupan yang cukup besar di pusat kota. Oleh karena itu keberadaan ruang terbuka publik di pusat kota, terutama ruang terbuka hijau di perkotaan sangat diperlukan karena fungsi dan peranannya sebagai tempat bagi masyarakat untuk melakukan sosialisasi dan rekreasi serta menjadi alternatif tempat istirahat untuk mencari udara segar di tengah kesibukan kegiatan di pusat kota yang begitu padat dan menghilangkan kepenatan setelah bekerja keras dengan biaya yang sangat murah. Adanya ruang terbuka hijau kota menjadi salah satu penyelesaian dalam peningkatan kualitas lingkungan perkotaan, dimana dampak yang paling mudah kita rasakan adalah pengaruhnya terhadap kesehatan, kenyamanan, estetika dan pelestarian lingkungan

Dalam kaitan itu, penataan ruang sebagai matra spasial pembangunan kota merupakan alat untuk mengkoordinasikan pembangunan perkotaan secara berkelanjutan (Eko Budihardjo, Djoko Sujarto. 1998). Selaras dengan amanat Undang-Undang Penataan Ruang Nomor 26 Tahun 2007 pasal 3, perlu diwujudkan suatu bentuk pengembangan kawasan perkotaan yang mengharmonisasikan lingkungan alamiah dan lingkungan buatan. Upaya untuk membangkitkan kepedulian masyarakat dan mewujudkan keberlangsungan tata kehidupan kota, antara lain dapat dilakukan dalam bentuk perwujudan Kota Hijau.

Kota hijau merupakan kota yang ramah lingkungan, yang memanfaatkan sumber daya air dan energi secara efektif dan efisien, mengurangi limbah, menerapkan sistem informasi terpadu, menjamin kesehatan lingkungan, serta mensinergikan lingkungan alami dan buatan. Kota Hijau merupakan kota yang ramah lingkungan dengan memanfaatkan secara, berdasarkan perencanaan dan perancangan kota yang sesuai dengan prinsipprinsip pembangunan berkelanjutan.

Selanjutnya di dalam tulisan ini akan dikaji seberapa besar capaian sasaran dan manfaat yang diperoleh dari pelaksaaan kegiatan Program Pengembangan Kota Hijau (P2KH) dan bagaimana peran seorang Arsitek dalam mengimplementasikan tercapainya besaran Ruang Terbuka Hijau (RTH) di Kawasan Perkotaan, sebagaimana diamanatkan di dalam Undang-Undang Penataan Ruang. Kajian ini bertujuan untuk meneliti seberapa besar capaian sasaran dan manfaat yang diperoleh dalam menambah besaran luasan Ruang Terbuka Hijau (RTH) di Kota Semarang, serta bagaimana peran seorang Arsitek dalam mengimplementasikan komponen guna mendukung terciptanya Kota Hijau.

\section{METODOLOGI PENELITIAN}

Secara umum, metode kajian ini terdiri dari :

1. Tahap Persiapan dan Pengumpulan data: Melakukan kajian awal terhadap peraturan yang berkaitan dengan penelitian, melakukan kajian awal terhadap kondisi lokasi perencanaan serta kondisi eksisting tata ruang hijau, yang dilakukan dengan cara pengumpulan data sekunder, survei instansional maupun survei lapangan.

Penelitian ini menggunakan Metode Rasionalistik berlandaskan pada cara berpikir rasionalisme, yang berasal dari pemahaman kemampuan intelektual dan dibangun atas kemampuan argumentasi secara logika, sehingga lebih ditekankan pada pemaknaan empiri (Sutrisno Hadi, 1984).

2. Tahap Identifikasi dan Kompilasi Data: Melakukan identifikasi dan kompilasi data baik yang bersifat primer, sekunder maupun data hasil survei mengenai wilayah perencanaan, kondisi tata ruang hijau dan kondisi vegetasi yang sudah diolah dalam bentuk kompilasi data.

Proses pengumpulan data dilakukan dengan cara survei yang terdiri dari survei data primer (lapangan) yang dilakukan dengan cara melakukan observasi lapangan, interview dengan nara sumber serta pengukuran lapangan. Sedangkan survei data sekunder (instansional), guna mendapatan data elemen pembentuk kota hijau serta data luasan Ruang Terbuka Hijau yang ada pada kawasan perkotaan di kota Semarang dilakukan dengan cara mengakses data dari dinas instansi teknis terkait serta melakukan kajian studi kebijakan pembangunan tentang RTH yang sudah pernah dilakukan. 
3. Tahap Analisis data: Menganalisis hasil Kompilasi Data, dimana proses analisis dilakukan terhadap wilayah perencanaan, analisis terhadap tata ruang hijau, baik secara spasial maupun parsial, serta analisis vegetasi.

Analisis data dilakukan dengan pendekatan kuantitatif dan kualitatif. Argumentasi dan pemaknaan empiri (termasuk di dalamnya hasil penelitian-penelitian terdahulu) menjadi penting sebagai dasar penelitian kualitatif yang berlandaskan pendekatan rasionalistik, sehingga pemahaman intelektual dan kemampuan berargumentasi secara logika akan didukung dengan data empirik dan diikuti dengan uji empiri secara terus menerus (Noeng Moehadjir, 2000). Sementara untuk mendukungnya, perlu dikembangkan kemampuan konseptualisasi teoritik yang disajikan secara terukur (kuantitatif). Bukan sekedar mempersiapkan obyek, tapi melihat fenomena dalam lokasi penelitian sebagai suatu kerangka yang holistik.

4. Tahap Penyusunan: penyajian dan penyusunan laporan penelitian menggunakan pendekatan deskriptif.

5. Hasil yang diharapkan yaitu teridentifikasinya komponen kota hijau yang dapat diaplikasikan pada Ruang Terbuka Hijau di Wilayah Kota Semarang. Kerangka pikir kedudukan RTH dalam wilayah perkotaan, dapat dilihat pada Gambar berikut :

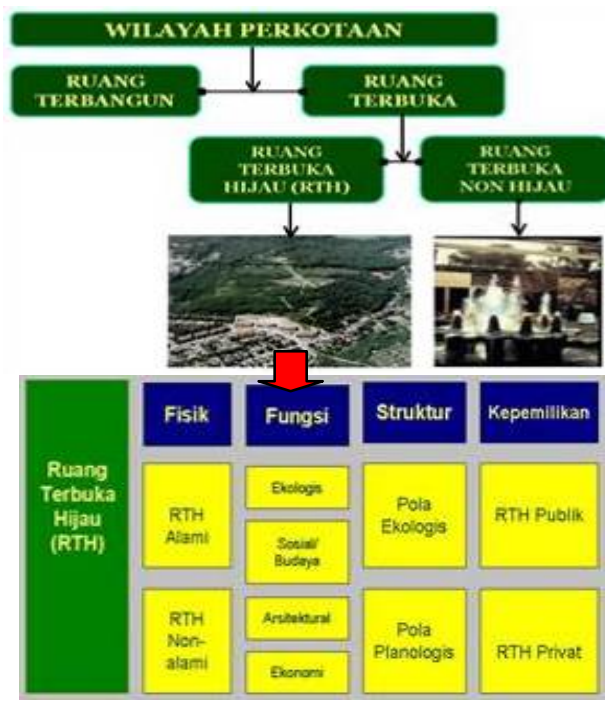

Gambar Kedudukan Ruang Terbuka Hijau dalam Wilayah Perkotaan

Sumber: Ning Purnomohadi. 2006. Ruang Terbuka Hijau Sebagai Unsur Utama Tata Ruang

\section{HASIL DAN PEMBAHASAN}

\section{Ruang Terbuka Hijau (RTH) dan Kota Hijau}

Tata Ruang Hijau/Ruang Terbuka Hijau mengacu pada ketentuan sebagaimana telah diatur dalam Instruksi Menteri Dalam Negeri Nomor 14 Tahun 1988 tentang Penataan Tata Ruang Hijau di Wilayah Perkotaan menerangkan bahwa Tata Ruang Hijau adalah bagian dari Ruang Terbuka, yaitu ruang-ruang dalam kota atau wilayah yang lebih luas baik dalam bentuk areal/kawasan maupun bentuk areal memanjang/jalur dimana dalam penggunaannya lebih bersifat terbuka yang pada dasarnya tanpa bangunan.

Dengan mengacu pada pengertian tersebut, maka pemanfaatan Tata ruang hijau lebih bersifat pengisian tanaman hijau atau tumbuhtumbuhan hijau seperti pada kawasan lahan pertanian, perkebunan, pertamanan, jalur hijau dan hutan kota

Ruang Terbuka adalah ruang-ruang dalam kota atau wilayah yang lebih luas baik dalam bentuk areal/kawasan maupun dalam bentuk areal memanjang/jalur dimana di dalam penggunaannya lebih bersifat terbuka yang pada dasarnya tanpa bangunan.

Fungsi hijau dalam RTH kota sebagai 'paru-paru kota', sebenarnya hanya merupakan salah satu aspek berlangsungnya fungsi daur ulang, antara gas karbondioksida $\left(\mathrm{CO}_{2}\right)$ dan oksigen $\left(\mathrm{O}_{2}\right)$ hasil fotosintesis khususnya pada dedaunan. Sistem tata hijau ini berfungsi semacam ventilasi udara dalam rumah/bangunan (Rustam Hakim, 1987). Lebih dari itu, masih banyak fungsi RTH termasuk fungsi estetika yang bermanfaat sebagai sumber rekreasi publik secara aktif maupun pasif, yang diwujudkan dalam sistem koridor hijau sebagai alat pengendali tata ruang lahan dalam suatu sistem RTH kota (urban park system). RTH juga berfungsi sebagai sumber penampungan air dan pengatur iklim tropis yang terik dan lembab (peneduh) (Ning Purnomohadi, 2006).

Ruang Terbuka adalah suatu wadah yang dapat menampung kegiatan/aktivitas tertentu dari warga lingkungan tersebut baik secara individu maupun kelompok (Rustam Hakim, 1993). Jenis ruang terbuka dibedakan sebagai berikut :

a. Ruang terbuka dalam lingkungan hidup :

Menurut Ian C. Laurint (dalam Rustam

Hakim, 1993) RTH dapat dibagi menjadi : 
1) Ruang terbuka sebagai sumber produksi antara lain berupa perhutanan, pertanian, peternakan, produksi mineral, dan lain-lain.

2) Ruang terbuka sebagai perlindungan terhadap kekayaan alam dan manusia, misalnya cagar alam berupa hutan, kehidupan laut/air, daerah budaya dan bersejarah.

3) Ruang terbuka untuk kesehatan, kesejahteraan dan kenyamanan, misalnya taman lingkungan, taman kota dan lain-lainnya.

b. Ruang terbuka ditinjau dari kegiatannya, dibagi menjadi dua jenis yaitu :

1) Ruang terbuka aktif adalah ruang terbuka yang mengundang unsur-unsur kegiatan di dalamnya, misalnya plaza, lapangan olah raga, tempat bermain, dan lain-lain

2) Ruang terbuka pasif adalah ruang terbuka yang di dalamnya tidak mengandung kegiatan manusia antara lain: penghijauan/taman sebagai sumber pengudara lingkungan

c. Ruang terbuka yang ditinjau dari bentuknya :

Menurut Rob Krier, ruang terbuka dapat dibagi menjadi dua yaitu

1) Berbentuk memanjang : Ruang terbuka pada bentuk memanjang pada umumnya hanya mempunyai batasbatas pada sisinya, misalnya: jalan, sungai dan lain-lainya

2) Berbentuk mencuat : Ruang terbuka pada bentuk mencuat pada umumnya yang mempunyai batas-batas di sekelilingnya, misalnya: lapangan, bundaran dan lain-lain

d. Ruang terbuka ditinjau dari sifatnya dapat dibedakan menjadi

1) Ruang terbuka lingkungan yaitu ruang terbuka yang terdapat pada suatu lingkungan dan sifatnya umum

2) Ruang terbuka bangunan yaitu ruang terbuka oleh dinding bangunan dan lantai halaman bangunan yang bersifat umum atau pribadisesuai dengan fungsi fungsi bangunannya

e. Ruang Terbuka ditinjau dari Fungsinya:

Ruang terbuka mempunyai peranan sebagai wadah yang dapat menampung aktivitas tertentu dari masyarakat wilayah tertentu, karena itu ruang terbuka mempunyai kontribusi yang akan diberikan kepada manusia yang berupa dampak positif. Sehingga fungsi ruang terbuka yaitu:

1) Fungsi umum ruang terbuka: Tempat bermain dan berolahraga, Tempat bersantai, Tempat komunikasi sosial, Tempat peralihan, tempat menunggu, Ruang terbuka untuk mendapatkan udara yang segar dari lingkungannya, Sarana penghubung antara suatu tempat dengan tempat yang lain, Pembatas/jarak diantara massa bangunan

2) Fungsi ekologis ruang terbuka adalah: Penyegar udara, Menyerap air hujan, Pengendali banjir, Memelihara ekosisitem tertentu, Pelembut arsitektur bangunan

f. Elemen Ruang Terbuka

Ruang terbuka terbentuk karena dipengaruhi oleh beberapa faktor, baik oleh lingkungan alam itu sendiri maupun lingkungan buatan. Faktor-faktor tersebut merupakan elemen yang dapat mempengaruhi ruang tersebut melalui ekspresi sifat unsurnya sampai batas tertentu. Adapun elemen ruang terbuka tersebut adalah :

1) Hard Material (elemen keras), seperti: bangunan, pagar, pedestrian dan furniture taman

2) Soft Material (elemen lunak), seperti tanaman, air dan sebagainya

Ruang umum (publik) merupakan bagian lingkungan yang berpola, terbentuk karena kebutuhan bertemu atau berkomunikasi manusia. Wadah yang menampung kegiatan tertentu, secara individu maupun kelompok. Bentuk ruangnya tergantung pola dan susunan massa bangunan. Menurut sifatnya, ruang umum terbagi menjadi :

a. Ruang tertutup umum, terletak dalam bangunan.

b. Ruang terbuka umum, terletak di luar bangunan, dipergunakan setiap orang dan multifungsi (jalan, pedestrian, taman lingkungan, plaza, lapangan olahraga, taman kota, taman rekreasi, dsb).

c. Ruang terbuka khusus, dimanfaatkan untuk kegiatan terbatas dan keperluan khusus (taman rumah tinggal, taman lapangan upacara, daerah lapangan terbang, area latihan militer). 
Kota Hijau merupakan salah satu strategi optimalisasi Ruang Terbuka Hijau untuk memenuhi ketetapan luasan minimal RTH sesuai Undang-Undang No. 26 Tahun 2007 tentang Penataan Ruang, terutama terkait pemenuhan luasan RTH perkotaan, sekaligus menjawab tantangan perubahan iklim di Indonesia. Kota Hijau merupakan konsep inovasi program perwujudan RTH perkotaan yang berbasis komunitas.

\section{Penerapan Metoda}

Atribut Kota Hijau adalah Komponen yang harus diterapkan pada Ruang Terbuka Hijau, sehingga secara inklusif dan komprehensif mampu memberikan manfaat sebagai Ruang Terbuka Publik yang cukup optimal bagi masyarakat secara luas, yang meliputi : Perencanaan dan perancangan kota yang ramah lingkungan (Green Planning and Design), Peningkatan peran masyarakat sebagai komunitas hijau (Green Community). Ketersediaan ruang terbuka hijau (Green Open Space), Konsumsi energi yang efisien (Green Energy), Pengelolaan air yang efektif (Green Water), Pengelolaan limbah dengan prinsip 3R (Green Waste), Bangunan hemat energi atau bangunan hijau (Green Building), Penerapan sistem transportasi yang berkelanjutan (Green Transportation),

Pada tahap inisiasi, Kota Hijau difokuskan pada perwujudan 3 (tiga) atribut, yaitu: perencanaan dan perancangan kota yang ramah lingkungan; perwujudan ruang terbuka hijau 30\%; dan peningkatan peran masyarakat melalui komunitas hijau. Pada tahap berikutnya diharapkan akan dapat lebih diperluas lagi.

3. Kajian dan Analisis Ketersediaan Besaran dan Sebaran Ruang Terbuka Hijau (RTH) Kota Semarang

a. Analisis Besaran RTH Kota Semarang

1) Perhitungan Luasan Ruang Terbuka Hijau Kota Semarang dihitung berdasarkan ketentuan Undang-Undang Penataan Ruang Nomor 26 Tahun 2007, maka Luas RTH minimal 30\% dari Luas Wilayah Kawasan Perkotaan adalah $=11.211,117 \mathrm{Ha}$

2) Berdasarkan Analisis Van Rooden (1977), standar RTH adalah 0,25 $\mathrm{m}^{2}$ dari jumlah penduduk $=19.541 \mathrm{Ha}$

3) Berdasarkan Metode Odum (1985), standar RTH adalah $15 \%$ dari Luas Wilayah $=5.605 .56 \mathrm{Ha}$.

4) Berdasarkan Perhitungan Eksisting RTH Kota Semarang sebesar = 15.894,56 На (42,53\%)

b. Analisis Sebaran RTH Kota Semarang Dari hasil analisa, dari 16 wilayah kecamatan di Kota Semarang, terdapat 8 wilayah yang prosentase luasan RTH nya kurang dari 30\%, yaitu Kecamatan Gajahmungkur, Candisari, Pedurungan, Gayamsari, Semarang Timur, Semarang Utara, Semarang Tengah dan Semarang Barat, seperti Tabel berikut :

Tabel 1. Sebaran RTH di Wilayah Kecamatan di Kota Semarang

\begin{tabular}{|c|c|c|c|c|c|}
\hline NO & KECAMATAN & $\begin{array}{c}\text { LUAS } \\
\text { WILAYAH } \\
\text { (HA) }\end{array}$ & $\begin{array}{l}\text { JUMLAH LUAS } \\
\text { RUANG HIJ AU } \\
\text { (HA) } \\
\end{array}$ & $\begin{array}{l}\text { \% LUAS RUANG } \\
\text { HIJAU THD } \\
\text { WILAYAH } \\
\end{array}$ & $\begin{array}{c}\text { SYARAT LUAS R HIJ AU } \\
30 \% \text { THD LUAS } \\
\text { WILAYAH }\end{array}$ \\
\hline 1 & MIJEN & $6.215,25$ & $5.145,39$ & 82,79 & Memenuhi \\
\hline 2 & GUNUNGPATI & $5.399,09$ & 3291,3900 & 60,96 & Memenuhi \\
\hline 3 & BANYUMANIK & $2.513,06$ & $2.048,06$ & 81,50 & Memenuhi \\
\hline 4 & GAJAH MUNGKUR & 764,98 & 57,24 & 7,48 & Tidak Memenuhi \\
\hline 5 & SEMARANG SELATAN & $\mathbf{8 4 8 , 0 5}$ & 373,66 & 44,06 & Memenuhi \\
\hline 6 & CANDISARI & 555,51 & $\mathbf{3 4 , 8 7}$ & 6,28 & Tidak Memenuhi \\
\hline 7 & TEMBALANG & $4.420,00$ & $1.684,60$ & 38,11 & Memenuhi \\
\hline 8 & PEDURUNGAN & $2.072,00$ & 501,00 & 24,18 & Tidak Memenuhi \\
\hline 9 & GENUK & $2.738,44$ & $1.368,36$ & 49,97 & Memenuhi \\
\hline 10 & GAYAMSARI & 549,47 & 105,58 & 19,21 & Tidak Memenuhi \\
\hline 11 & SEMARANG TIMUR & 770,25 & 73,45 & 9,54 & Tidak Memenuhi \\
\hline 12 & SEMARANG UTARA & $1.133,28$ & 107,34 & 9,47 & Tidak Memenuhi \\
\hline 13 & SEMARANG TENGAH & 604,99 & 72,01 & 11,90 & Tidak Memenuhi \\
\hline 14 & SEMARANG BARAT & $2.386,71$ & 667,78 & 27,98 & Tidak Memenuhi \\
\hline 15 & TUGU & $3.129,34$ & $1.911,25$ & 61,08 & Memenuhi \\
\hline \multirow[t]{2}{*}{16} & NGALIYAN & $3.269,97$ & $2.641,97$ & $\mathbf{8 0 , 7 9}$ & Memenuhi \\
\hline & JUMLAH & $37.370,39$ & $20.083,95$ & $20.083,95$ & \\
\hline
\end{tabular}

Sumber : Bappeda Kota Semarang 
Tabel 2. Jumlah Sebaran Taman yang Dikelola Dinas Pertamanan di Kota Semarang

\begin{tabular}{|c|c|c|c|c|c|}
\hline No & SEKTOR & $\begin{array}{c}\text { JENIS TAMAN } \\
\text { AKTIF }\end{array}$ & $\begin{array}{c}\text { JENIS TAMAN } \\
\text { PASIF }\end{array}$ & $\begin{array}{c}\text { JU MLAH } \\
\text { (BH) }\end{array}$ & LUAS (M2) \\
\hline 1 & PERTAMANAN SEMARANG UTARA & 8 & 6 & 14 & $7.160,15$ \\
\hline 2 & PERTAMANAN SEMARANG TENGAH & 2 & 27 & 29 & $23.019,15$ \\
\hline 3 & PERTAMANAN SEMARANG TIMUR & 11 & 21 & 32 & $17.956,00$ \\
\hline 4 & PERTAMANAN SEMARANG BARAT & 1 & 13 & 14 & $15.343,00$ \\
\hline 5 & PERTAMANAN SEMARANG SELATAN & 6 & 10 & 16 & $24.049,00$ \\
\hline 6 & PERTAMANAN CANDISARI & 1 & 9 & 10 & $10.638,34$ \\
\hline 7 & PERTAMANAN GAJAHMUNGKUR & 2 & 14 & 16 & $21.603,00$ \\
\hline 8 & PERTAMANAN GAYAMSARI & 1 & 1 & 2 & 1.914 .00 \\
\hline 9 & PERTAMANAN PEDURUNGAN & 1 & 0 & 1 & 588,00 \\
\hline \multirow[t]{2}{*}{10} & PERTAMANAN BANYUMANIK & 5 & 8 & 13 & $12.595,01$ \\
\hline & TOTAL & 38 & 109 & 147 & $134.937,65$ \\
\hline
\end{tabular}

Sumber : Bappeda Kota Semarang

Tabel 3. Jumlah Sebaran Taman Per Kecamatan di Kota Semarang

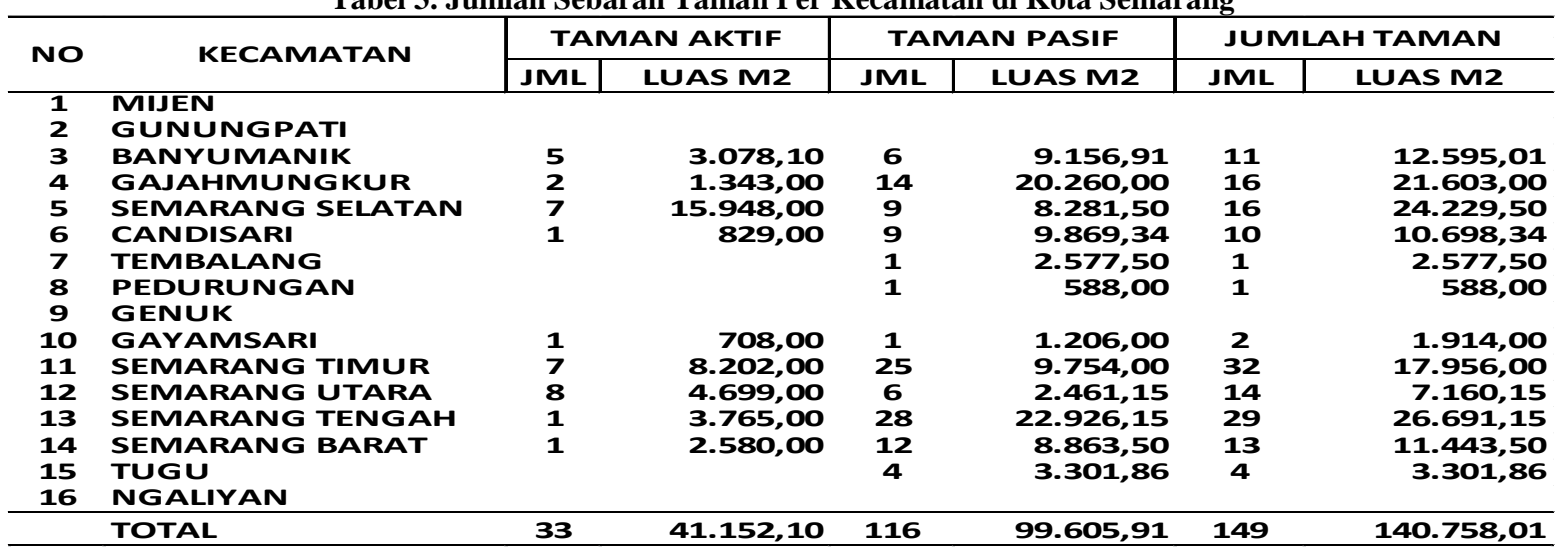

Sumber : Bappeda Kota Semarang

\section{Penentuan Lokasi Perancangan RTH} Kota Hijau

Ruang Terbuka Hijau (RTH) kota bermanfaat mengisi hijau tumbuhan dan pemanfaatannya bagi kegiatan masyarakat. Berdasarkan tata letaknya, RTH kota bisa berwujud ruang terbuka kawasan pantai (coastal open space), dataran banjir sungai (river flood plain), ruang terbuka pengaman jalan bebas hambatan (greenways) dan ruang terbuka pengaman kawasan bahaya kecelakaan di ujung landasan bandar udara. Secara makro, RTH kota meliputi ;

1. RTH makro, seperti kawasan pertanian, perikanan, hutan lindung, hutan kota dan landasan pengaman bandar udara.

2. RTH medium, seperti kawasan area pertamanan (city park), sarana olahraga, pemakaman umum.

3. RTH mikro, yaitu lahan terbuka yang ada di setiap kawasan permukiman yang disediakan dalam fasilitas umum seperti taman bermain (play ground), taman lingkungan (community park) dan lapangan olahraga.
Secara sistem, RTH kota adalah bagian kota yang tidak terbangun, yang berfungsi menunjang keamanan, kesejahteraan, peningkatan kualitas lingkungan dan pelestarian alam. Umumnya terdiri dari ruang pergerakan linear atau koridor dan ruang pulau atau oasis (Spreigen, 1965). Atau path sebagai jalur pergerakan dan room sebagai tempat istirahat, kegiatan atau tujuan (Krier, 1975). Dapat berbentuk buatan manusia dan alam yang terjadi akibat teknologi, seperti koridor jalan dan pejalan kaki, bangunan tunggal dan majemuk, hutan kota, aliran sungai, dan daerah alamiah yang telah ada sebelumnya. Ringkasnya, totalitas kesatuan yang memiliki keterkaitan dan dapat digunakan sebagai sistem orientasi.

Untuk kegiatan implementasi fisik peningkatan kualitas dan kuantitas RTH, harus dipilih lokasi yang strategis dan representatif dalam skala perkotaan. Hal ini dikarenakan kegiatan pembangunan RTH tersebut hanya berfungsi sebagai stimulus untuk keberlangsungan pemenuhan luasan RTH di masa yang datang. 
Sehingga diharapkan lokasi dan desain RTH yang akan dibangun dapat memberikan efek leverage yang secara signifikan menambah luasan RTH kota dan meningkatkan kualitas hidup masyarakat perkotaan secara keseluruhan.

Lokasi prioritas pembangunan RTH tersebut harus ditetapkan melalui SK Walikota sehingga berkekuatan hukum. Kriteria lokasi RTH yang strategis dalam konteks Kota Hijau adalah sebagai berikut:

1. Berada di pusat kegiatan sosial ekonomi kota/kawasan perkotaan;

2. Status lahan milik pemerintah daerah;

3. Kedekatan dengan pusat kegiatan masyarakat kota, serta bisa digunakan untuk public;

4. Aplikasi pembangunan pada 1 (satu) lokasi dengan luasan minimal $5.000 \mathrm{~m} 2$ atau pada 2 (dua) lokasi yang dihubungkan dengan koridor penghubung 'hijau' misal jalur sepeda, jalur vegetasi, atau bentuk lain);

5. Komposisi Ruang Hijau (Softcape) : Perkerasan (Hardscape) $=\min .70 \%$ : max.30\% berupa material ramah lingkungan (bisa dimungkinkan untuk menyerap air);

6. Mudah diakses oleh publik (berdekatan dengan prasarana dan sarana transportasi umum);

7. Dapat berupa lokasi yang menjadi landmark kota seperti: situ, sempadan sungai, hutan kota, taman kota.

\section{Penerapan Atribut Hijau dalam Desain RTH Kota Hijau}

Atribut hijau yang sudah diaplikasikan di perencanaan taman ramah lingkungan sesuai Konsep Kota Hijau di Kota Semarang adalah sebagai berikut:

1. Perencanaan dan perancangan kota yang ramah lingkungan (Green Planning and Design), diaplikasikan pada Desain Taman RTH di kawasan Rejomulyo (2012) serta lahan bekas Pasar Sampangan (2013)

2. Peningkatan peran masyarakat sebagai komunitas hijau (Green Community) dilakukan dengan membentuk Komunitas Hijau di tingkat Kelompok Masyarakat Sistem Penggunaan Taman, untuk kegiatan komunitas masyarakat setempat sehingga taman berfungsi optimal sebagai wadah interaksi sosial

3. Ketersediaan ruang terbuka hijau (Green Open Space), diaplikasikan dalam pemilihan jenis vegetasi lokal (endemik), vegetasi peneduh (penyerap polutan atau pereduksi emisi karbon), vegetasi pembentuk iklim mikro, vegetasi produsen oksigen, vegetasi penarik satwa liar

4. Konsumsi energi yang efisien (Green Energy), diaplikasikan dalam sistem penyedia sumber listrik dari matahari, dengan pemakaian panel surya (Solar Cell)

5. Pengelolaan air yang efektif (Green Water), diaplikasikan pada sistem pengolahan dan penggunaan ulang (daur ulang) air, dalam bentuk : pembuatan sumur resapan air, pembuatan kolam penampung air, pengolahan atau penggunaan kembali air bekas, misalnya dari air dari toilet untuk penyiraman tanaman.

6. Pengelolaan limbah dengan prinsip 3R (Green Waste), diaplikasikan dalam bentuk sistem pengolahan dan penggunaan material bekas (sampah), dengan cara pemilahan sampah menggunakan tempat sampah organik-anorganik, pengolahan sampah organik menjadi kompos dengan komposter untuk pemeliharaan/pemupukan taman itu sendiri, penggunaan furniture hijau (terbuat dari bahan daur ulang) di dalam taman

7. Bangunan hemat energi atau bangunan hijau (Green Building), diaplikasikan dalam bentuk naungan sederhana, sebagai sarana pendukung utama taman, dari material ramah lingkungan dengan penghawaan alami (shelter/halte bus, gazebo, pergola, toilet)

8. Penerapan sistem transportasi yang berkelanjutan (Green Transportation), diaplikasikan pada sistem kemudahan \& kenyamanan aksesibilitas, dalam bentuk : trotoar tepi jalan taman, jalur pejalan kaki dalam taman dan jalur/parkir sepeda.

\section{Aplikasi Desain RTH Kota Hijau Taman Sampangan Kota Semarang}

Taman Sampangan direncanakan berlokasi di Jalan Kelud, yang merupakan perempatan dari arah Jalan Lamongan, Jalan Menoreh, Jalan Kelud dan Jalan Papandayan. Merupakan lahan bekas Pasar Sampangan, yang awalnya menjadi Pusat Kegiatan Ekonomi di sekitar Kawasan Sampangan Kota Semarang.

Setelah pemindahan Pasar Sampangan sebagai dampak Rehabilitasi Sungai 
Kaligarang dan Proyek Pembangunan Bendungan Jatibarang, maka lokasi Pasar Sampangan yang berada di Lahan Sempadan Sungai Kaligarang harus dikembalikan pada fungsi semula yaitu sebagai Kawasan Lindung Sempadan Sungai.
Menempati lahan seluas $3.009 \mathrm{~m}^{2}$. Awalnya tanah kosong ini dimanfaatkan untuk kegiatan sektor informal, terutama saat sore dan malam hari. Lapangan bekas bangunan pasar di bagian tengah serig dimanfaatkan anak-anak sekitar untuk bermain bola pada saat hari libur.

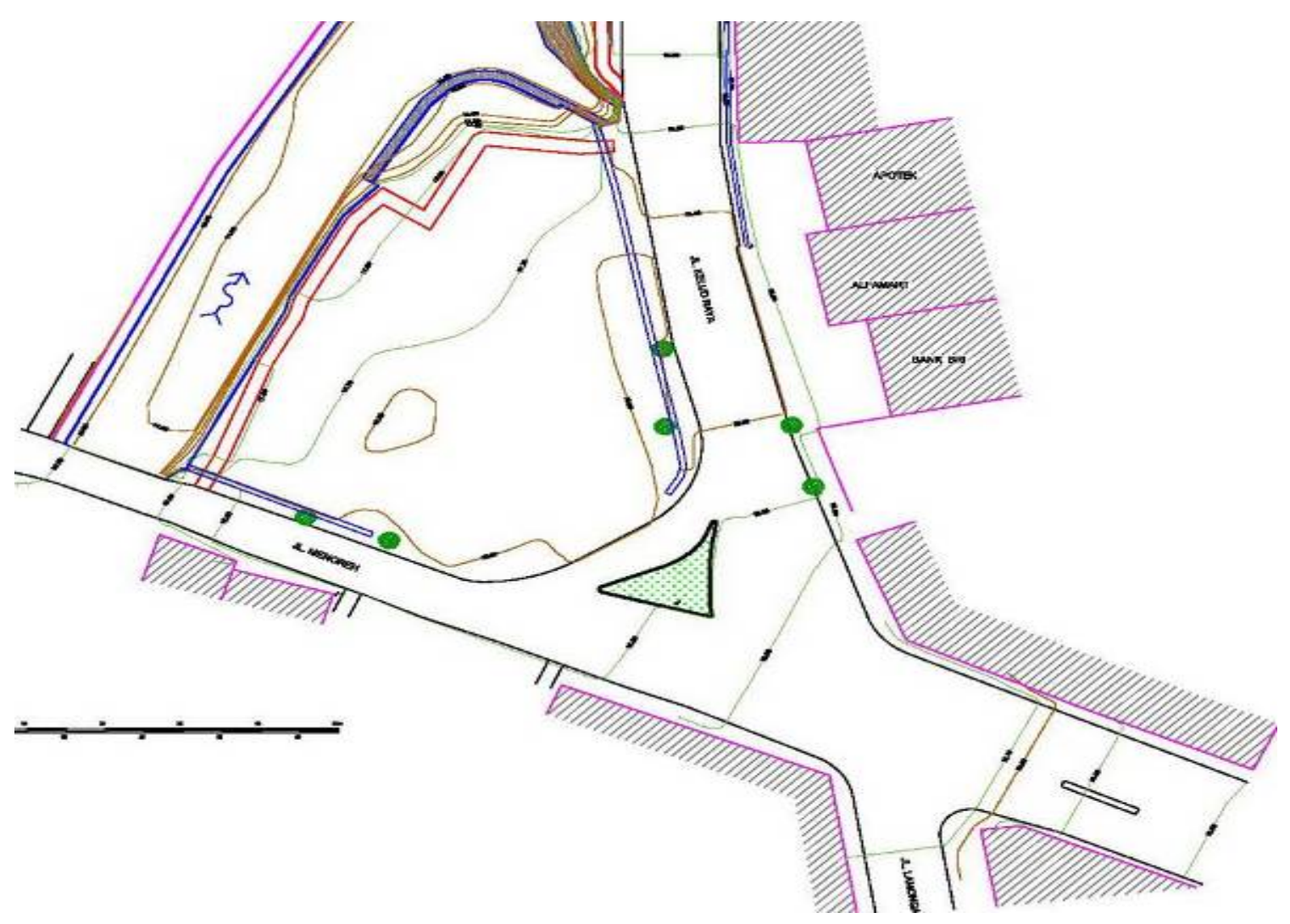

Gambar 2. Lokasi Pembangunan Taman Sampangan

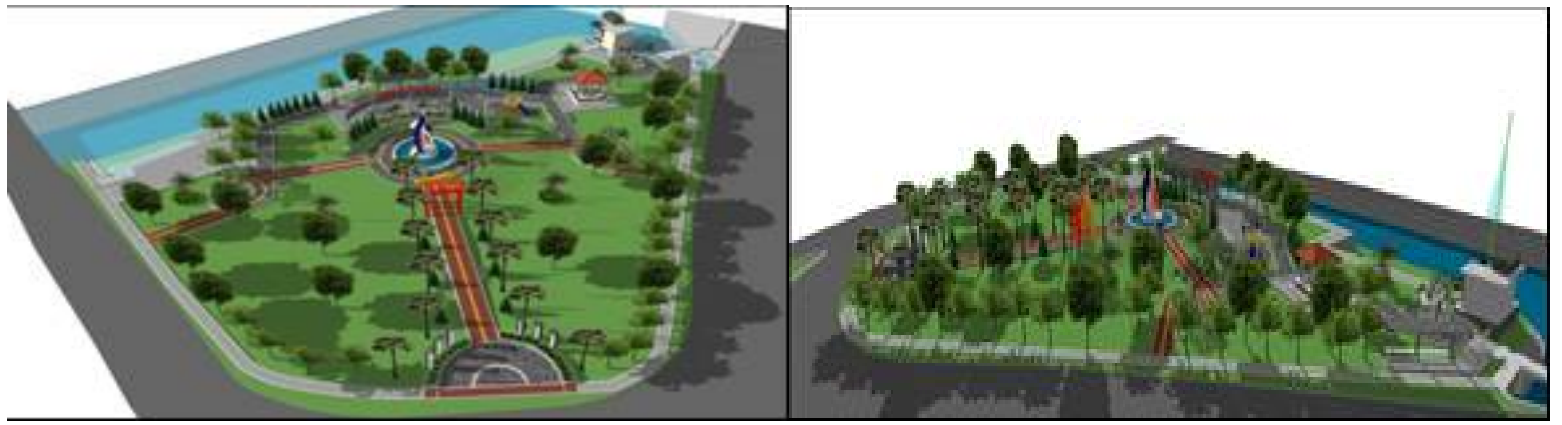




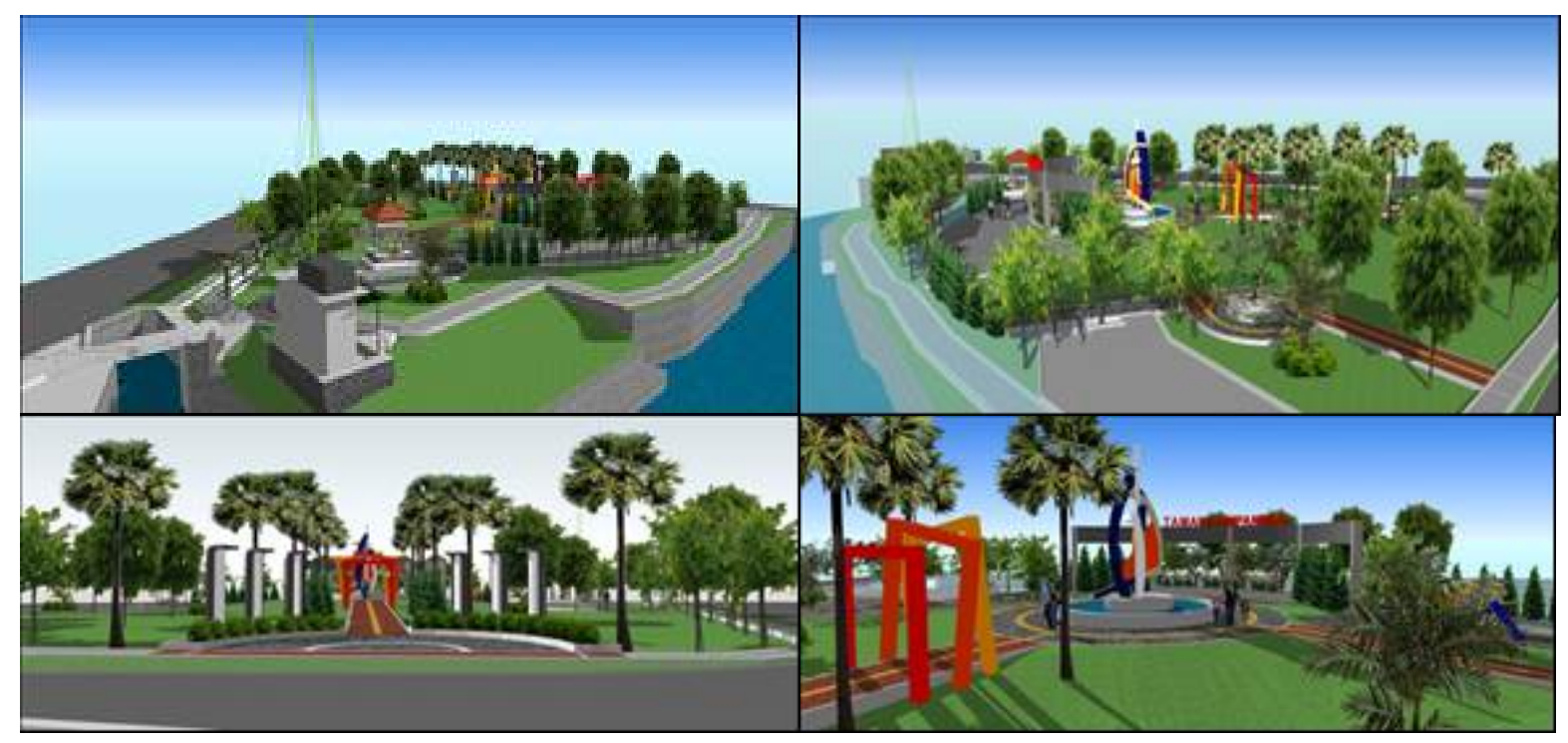

Gambar 3. Desain Taman Sampangan (Sampangan Youth Park)

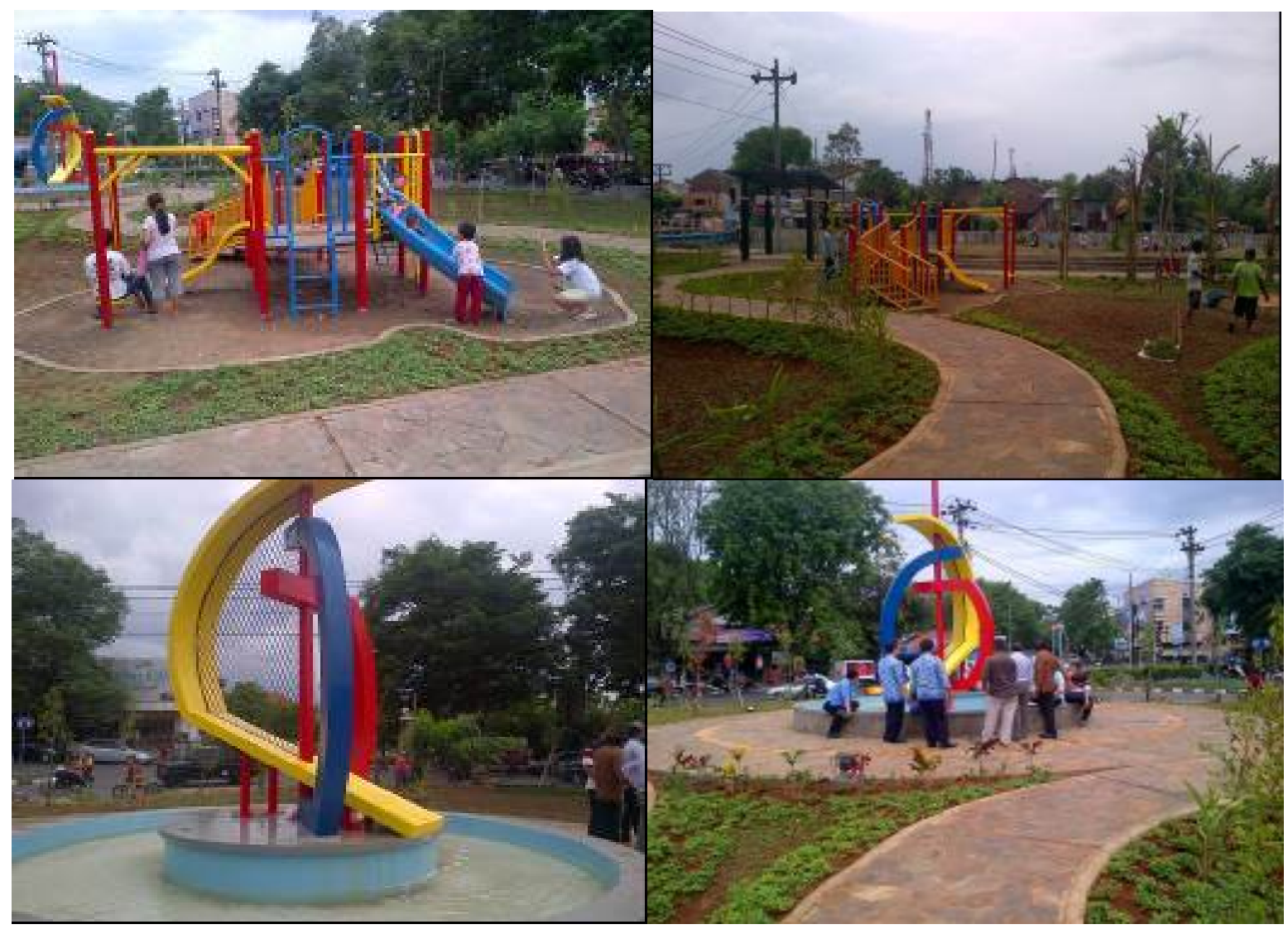

Gambar 4. Sculpture dan Arena Bermain Anak di Taman Sampangan 


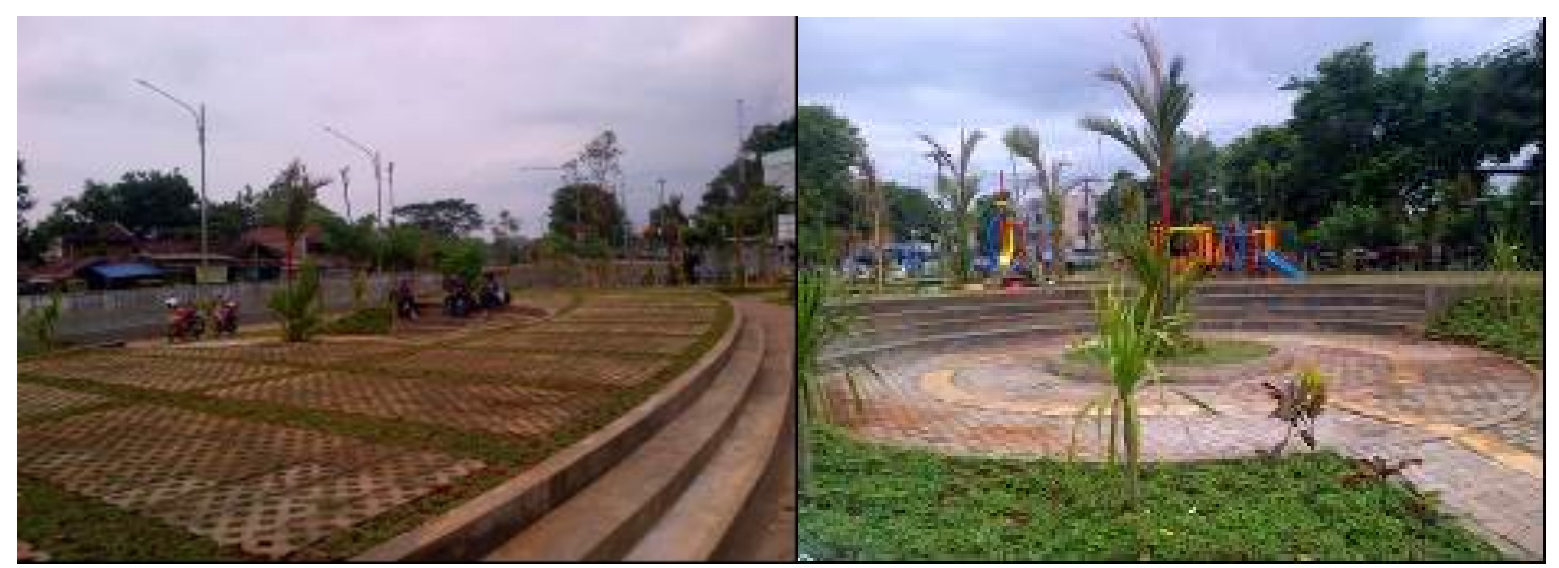

Gambar 5. Plaza Utama di Taman Sampangan

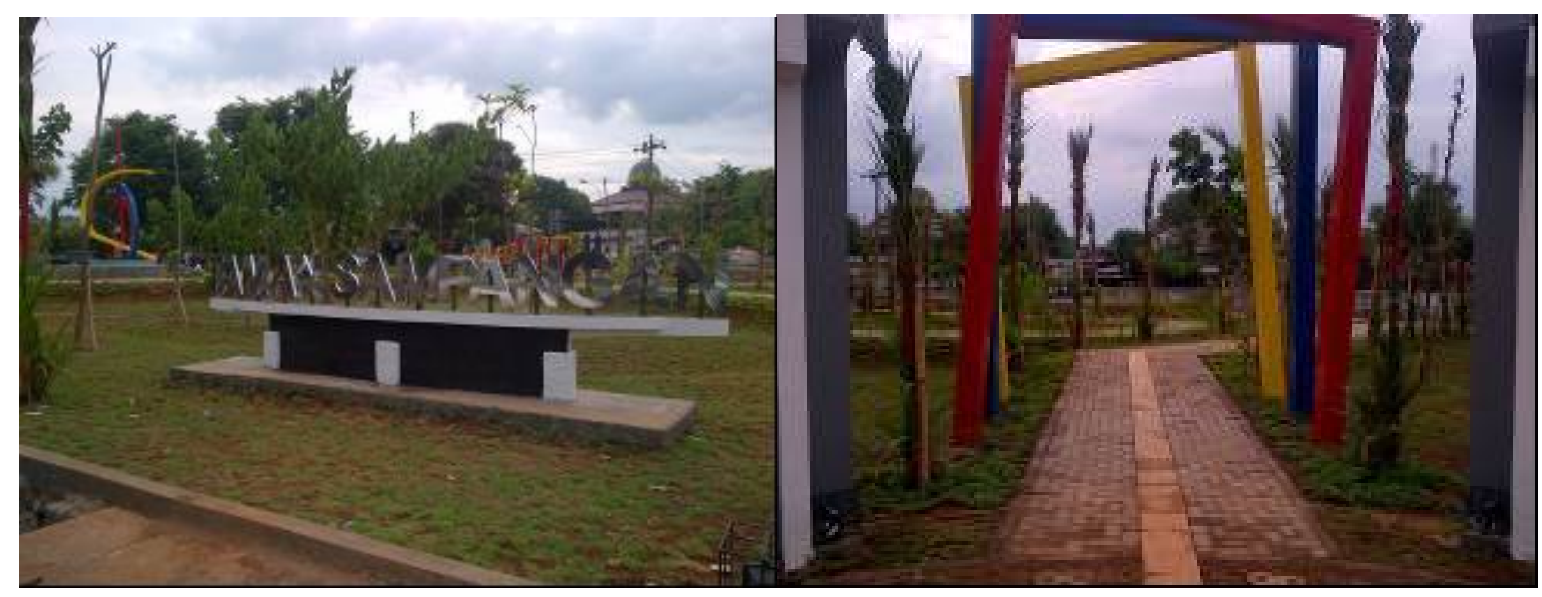

Gambar 6. Nama Taman dan Gerbang Utama di Taman Sampangan

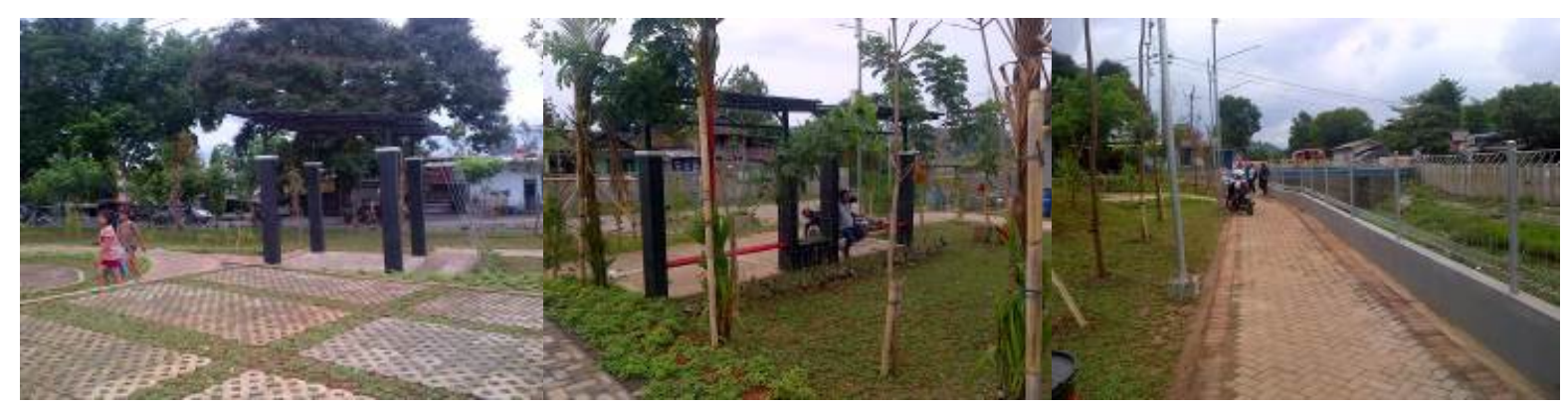

Gambar 7. Fasilitas Gazebo, Shelter dan Jalur Pedestrian di Taman Sampangan

Taman Sampangan didesain dengan konsep Taman Untuk Anak Muda / Youth Park, dengan tujuan sebagai Pusat Kegiatan anak muda di sekitar Kawasan Sampangan. Untuk menampung aktivitas yang ada, Taman Sampangan di desain dengan dilengkapi fasilitas seperti Plaza Utama, Jalur Pedestrian, Taman dengan berbagai macam tanaman yang bervariasi, Gazebo, Shelter, Tempat Parkir Sepeda, Bangunan Service dan Toilet, Sculpture dan Air Mancur, Solar Cell untuk penerangan Jalur Pedestrian serta Fasilitas WIFI untuk sambungan internet.

Meskipun berada di perempatan Jalur Utama di Kawasan Sampangan, orientasi Taman menghadap ke arah Sungai Kaligarang (Waterfront), dengan menempatkan Plaza Utama sebagai “Tujuan Akhir / Ending Destination" yang menghadap ke arah Sungai Kaligarang. Dengan konsep tersebut, diharapkan keberadaan Taman terintegrasi dengan Sungai, dimana Sempadan Sungai 
dimanfaatkan sebagai Taman Kota, yang selain berfungsi sebagai Pemanfaatan Ruang Terbuka Hijau (RTH) Sempadan Sungai, juga bermanfaat sebagai Ruang Terbuka Publik, yang berfungsi Ekonomis Rekreatif dan Sosial bagi masyarakat di sekitar Kawasan, yang didominasi oleh Kawasan Perumahan dan Permukiman.

\section{KESIMPULAN}

1. Secara Kuantitas dan Kualitas, Sebaran dan Besaran Ruang Terbuka Hijau di wilayah Kota Semarang masih perlu ditingkatkan lagi.

2. Masih sangat sulit untuk menyediakan luasan lahan yang cukup yang dapat dimanfaatkan sebagai Ruang Terbuka Hijau baru. Upaya untuk memanfaatkan lahan kosong, lahan kritis, sempadan sungai dan lahan bekas bongkaran bangunan publik merupakan salah satu upaya untuk menambah luasan RTH di Kawasan Perkotaan.

3. Penyediaan RTH dengan konsep Kota Hijau yang mengaplikasikan Atribut Hijau di dalam desainnya, merupakan salah satu strategi untuk menyediakan Ruang Terbuka Publik yang mengacu pada konsep Pembangunan Berkelanjutan.

4. Kegiatan yang sudah dilaksanakan Pemerintah Kota Semarang dengan membangun RTH Taman Kota / Taman Kawasan dengan konsep Kota Hijau di atas lahan bekas Pasar Rejomulyo (Tahun 2012) dan lahan bekas Pasar Sampangan (Tahun 2013) akan menjadi contoh pembangunan taman-taman lain di wilayah Kota Semarang.

5. Masih perlu dilakukan sosialisasi dan pendampingan di tingkat masyarakat untuk ikut memelihara dan bertanggung jawab terhadap keberlangsungan taman yang sudah dibangun, agar elemen penunjang taman tetap terpelihara dengan baik, tidak mudah rudak dan tidak cepat hilang, serta agar tanaman yangf ditanam di dalam taman dapat hidup dengan subur.

\section{DAFTAR PUSTAKA}

Budihardjo, Eko dan Djoko Sujarto. 1998. Kota Yang Berkelanjutan. Direktorat Jenderal Pendidikan Tinggi, Departemen Pendidikan Dan Kebudayaan.
Dicky, Yohanes, Bappeda Kota Semarang, 2010, Rencana Tata Ruang Wilayah (RTRW) Kota Semarang 2010-2030.

Dicky, Yohanes, 2012, Program Pengembangan Kota Hijau (P2KH). Project Study Dinas Cipta Karya Kementrian Pekerjaan Umum Kabupaten Kendal.

Dicky, Yohanes, 2013, Kegiatan Pengembangan Pemanfaatan Ruang Kota Hijau Kota Semarang Provinsi Jawa Tengah Pekerjaan Penyusunan Detail Engineering Design (DED) P2KH RTH Taman Sampangan Kota Semarang, Tahun Anggaran 2013

Hadi, Sutrisno, 1984, Metodologi Reserarch, Jilid 1 dan 2, Yayasan Penerbit Fakultas Psikologi Universitas Gajah Mada, Yogyakarta.

Hakim, Rustam, 1987, Unsur Perancangan dalam Arsitektur Lansekap, Bina Aksara, Jakarta.

Krier, Rob. 1979. Urban Space. Academic Editions 42 Leinster Gardens, London.

Muhadjir, Noeng, 2000, Metodologi Penelitian Kualitatif Edisi IV, Rake Sarasin, Yogyakarta.

Ning Purnomohadi. 2006. Ruang Terbuka Hijau Sebagai Unsur Utama Tata Ruang Kota,. Direktorat Jenderal Penataan Ruang, Departemen Pekerjaan Umum, Jakarta.

Schultz, Christian Norberg. 1988. Architecture : Meaning and Place. Electa / Rizzoli, New York.

Speiregen, Paul D. 1965. Urban Design : The Architecture Of Towns And Cities. Mc. Graw Hill Book Company, New York.

Sumarwoto, Otto. 1989. Ekologi Lingkungan Hidup Dan Pembangunan. Penerbit Djambatan, Jakarta

Van Rooden, 1977, Green Space In. Cities City Lanscape. 